\title{
Unit Root Test of Import and Export Seaborne Trade in Nigeria Seaports
}

\author{
Okoroafor, Ikechukwu Benedict ${ }^{1}$, Obaji, Ifeoma ${ }^{2}$ and Nwabueze, Joy Chioma ${ }^{3}$. \\ ${ }^{1}$ Pre-ND Program Basic Sciences, Federal College of Agriculture Ishiagu, Ebonyi State,Nigeria. \\ ${ }^{3}$ Department of Statistics, Michael Okpara University of Agriculture, Umudike Abia State,Nigeria. \\ ${ }^{2}$ Lokpanta Secondary School Umuchieze, Umunneochi, Abia State, Nigeria.
}

\begin{abstract}
This study applies Dickey-Fuller test for unit root to import and export data on seaborne trade figure in Nigeria. The Dicky-Fuller test shows that both data series are non-stationary. First differencing of the data stationarized it and ordinary least squares regression analysis applied to the data shows a significant relationship between export and import trade in Nigeria.. the graph of the data shows that there was an upward trend in both import and export. Evaluation statistics of tau, R-square and F-ratio were used for the estimated model.
\end{abstract}

Key words: Import, Export, Seaport, unit root test and Dickey - Fuller.

\section{Introduction}

In time series Econometrics, a unit root is a feature of processes that evolve through time that can cause problems in statistical inference if it is not adequately dealt with. A linear stochastic process has a unit root if one is a root of the process's characteristic equation such a process is non-stationary. If the other roots of the characteristic equation lie inside the unit circle- that is, have a modules (absolute value) less than one then, the first difference of the process will be stationary. A stochastic process is said to be stationary if its mean and variance are constant over time and the value of the covariance between the two time periods depends only on the distance or gap or lag between the two time periods and not the actual time at which the covariance is computed. In time series, such a stochastic process is known as a weakly stationary, or covariance stationary or second-order stationary or wide series, stochastic process Omekara (1995). At one time, conventional wisdom was that in order to apply standard inference procedures in such studies, the variables in the system needed to be stationary since the vast majority of econometric theory is built upon the assumption of stationarity. Consequently, for many years econometricians preceded as if stationarity could be achieved by simply removing deterministic components (e.g., drifts and trends) from the data. However, stationary series should at least have constant unconditional mean and variance over time, a condition which hardly appears to be satisfied in economics, even after removing those deterministic components (e.g, drifts and trends) from the data. These problems were somehow ignored in applied work until important papers by Granger and Newbold (1974) and Nelson and Plosser (1982) alerted many to the econometric implications of non-stationarity and the dangers of running nonsense or spurious regressions. In particular, most of the attention focused on the implications of dealing with integrated variables which are a specific class of non-stationary variables with important economic and statistical properties. These are derived from the presence of unit roots which give rise to stochastic trends, as opposed to pure deterministic trends, with innovations to an integrated process being permanent rather than transitory.

Statisticians, in turn, following the influential approach by Box and Jenkins (1979), had advocated transforming integrated time series into stationary ones by successive differencing of the series before modelization. Therefore, from their viewpoint, removing unit roots through differencing ought to be a prerequisite for regression analysis. The presence of, at least, a unit root in economic time series is applied in many economic models, among them, there are those based on the rational use of available information or the existence of very high adjustment costs in some markets. Some authors have used unit root test in their studies. Notable among them is Achike et al (2011) who applied cointegration and unit root test in their analysis of determinants of agricultural foreign direct investment in Nigeria. Danilowska (2008) investigated the impact of macroeconomic determinants on the number and value of agricultural investment preferential credits in Poland. The result showed that the determinants are of an exogenous character and that the statistically significant variables in the case of the measures were the index of price relations of sold agricultural products to goods and services purchased by private farms.

In this work, unit root test was studied on annual import and export seaborne trade through the Nigeria seaport (1995-2005) as published by National Bureau of Statistics Nigeria, to measure import and export as referenced. 


\section{Theoretical Framework}

The basic theoretical problem which will be considered in this work is based on the application of unit root test and ordinary least square (OLS) regression model. According to Gujarati (2006 \& 2009), Greene (2008), Engle and Granger (1987) and Razzak (2007) if one is dealing with time series data, he must be certain that the individual time series are either stationary or that they are cointegrated. If this is not so, one may be opened to spurious regression analysis. A time series is said to be stationary in the above context if its mean and variance are constant over time and the value of the covariance between two time periods depends only on the distance or lag between the two time periods and not on the actual time at which the covariance is computed Bannerjee et al (1993).

\section{Methodology}

Secondary data, mainly time series data from Central Bank of Nigeria's annual report containing data from import and export on seaborne trade through Nigeria seaports data were used for this study. The data collected covered a period of 51 years $(1955$ - 2005).

\section{Analytical Framework.}

Based on the theoretical framework presented and the research objectives, the following methods were used in attaining the objectives of this research: First the data were plotted graphically to look at the trend movement. If the graph moves continuously upwards or downwards, then, we suspect that the data is not stationary, otherwise it is stationary. The graph is presented in fig. 1. Also the data was analyzed using Ordinary Least Square (OLS) Regression Model. Furthermore, the data were subjected to unit root test using Dickey Fuller (DF).

\section{Analytical Techniques.}

Ordinary Least Square (OLS) Regression Model.

According to Gujarati (2006, 2009), OLS model is given by:

$$
\begin{aligned}
Y_{\text {it }}=\beta_{1}+ & \beta_{2} X_{2 i t}+\beta_{3} X_{3 i t}+\ldots+\beta_{k} X_{k i t}+\mu_{\text {it }} \\
& i=1,2, \ldots, k \text { and } t=1,2,3, \ldots, n
\end{aligned}
$$

where $\mathrm{i}$ stands for the $\mathrm{i}^{\text {th }}$ cross sectional units (sectors) and $\mathrm{t}$ stands for the $\mathrm{t}^{\text {th }}$ time period (years) which are the cross sectional identifier and the time identifier respectively. $\beta_{1}$ is a constant. $\beta_{2}, \beta_{3}, \ldots, \beta_{\mathrm{k}}$ are the regression coefficients. $Y_{i t}$ is the dependent variable while $X_{2}, X_{3}, \ldots, X_{k}$ are the independent variables. In this work, Ordinary Least Squares (OLS) regression was applied to investigate the relationship between import and export when coefficients are constant across time, and individuals (import and export). This is achieved by pooling all the observations together, Thus, equation (1a) could be written as:

$$
\begin{aligned}
\operatorname{Exp}_{\mathrm{it}}= & \beta_{1}+\beta_{2} \operatorname{Imp}_{2 \mathrm{it}}+\mu_{\mathrm{it}} \\
& \mathrm{i}=1, \text { and } \mathrm{t}=1,2,3, \ldots, 51
\end{aligned}
$$

where Exp $=$ Export, Imp $=$ Import while $\mu$ is the error term estimating equation (1a), the results obtained are shown in Table 1.

\section{Dickey -Fuller (DF) Test.}

The Dickey-Fuller test tests whether a unit root is present in an autoregressive model. A simple AR (1) model is

$$
Y_{t}=\rho Y_{t-1}+\mu_{t}
$$

where $\mu_{t}$ is a white noise error term

We test to find out whether or not $\rho=1$. If it is, then we claim that the series is not stationary. It contains a unit root. But equation (1) would be estimated by subtracting $\boldsymbol{Y}_{\boldsymbol{t}-\mathbf{1}}$ from both sides of the equation to obtain:

i.e

$$
Y_{t}-Y_{t-1}=\rho Y_{t-1}-Y_{t-1}+\mu_{t}
$$

$$
\Delta Y_{t}=\delta Y_{t-1}+\mu_{t}
$$

where $\boldsymbol{\delta}=\boldsymbol{\rho}-\mathbf{1}$ and $\Delta$, the difference operator. In practice, instead of estimating (2), we estimate (4) and test the null hypothesis that $\delta=0$. If $\delta=0$, then, $\boldsymbol{\rho}=1$ meaning that the time series is non-stationary. The data will therefore be estimated as follows: Equation (4) will be estimated by OLS. The estimated coefficient of $\boldsymbol{Y}_{\mathrm{t}-1}$ will be divided by its standard error to obtain the tau statistic. See (Gujarati and Porter 2009), (Dickey and Fuller 1979), (Stock and Watson 1990) and (Stock 1994). The results are presented in Table 2a and 2b. 


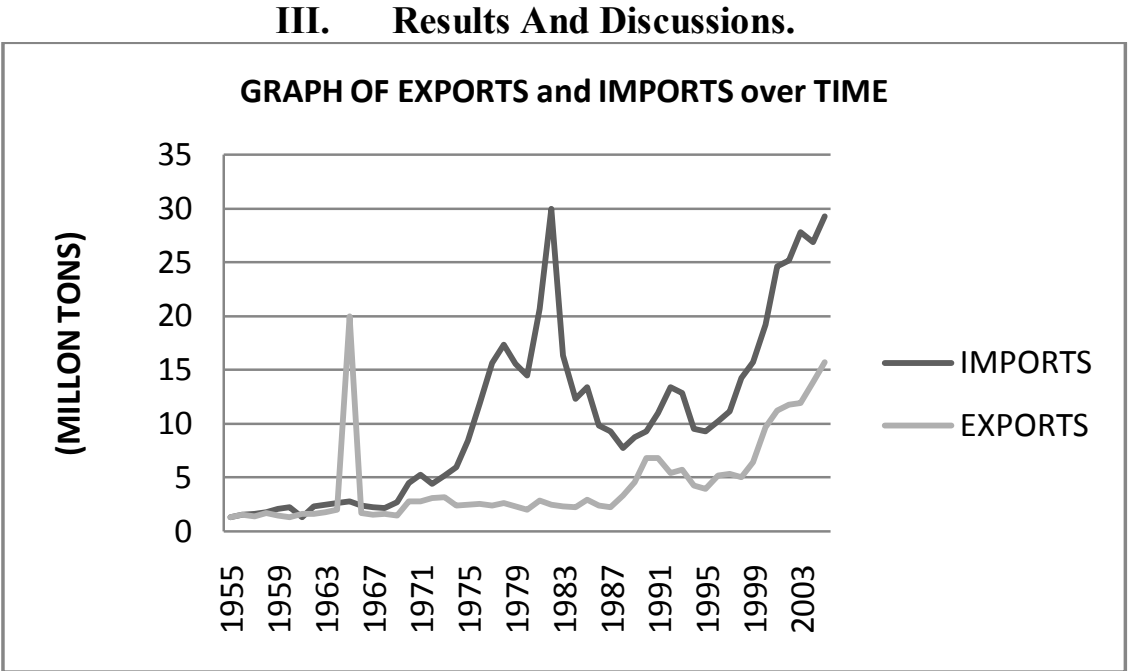

Fig 1:

The graphs in fig. 1 above, shows both the Export and Import data moving together. Import appears to be higher than Exports within the study period. The figure also shows that there was an upward trend in both import and export signifying that import and export data are not stationary.

\section{Table 1: Regression Analysis Of Exports And Imports}

\begin{tabular}{|c|c|c|}
\hline Source & SS & MS \\
\hline Model | & $2.4978 \mathrm{e}+14$ & $2.4978 \mathrm{e}+14$ \\
\hline Residual | & | $5.8914 \mathrm{e}+14$ & $49 \quad 1.2023 \mathrm{e}+13$ \\
\hline
\end{tabular}

Number of obs $=51$

$$
\begin{aligned}
\mathrm{F}(1, \quad 49) & =20.77 \\
\text { Prob }>\mathrm{F} & =0.0000 \\
\text { R-squared } & =0.2977 \\
\text { Adj R-squared } & =0.2834 \\
\text { Root MSE } & =3.5 \mathrm{e}+06
\end{aligned}
$$

\begin{tabular}{rcccccc} 
export $\mid$ & Coef. & Std. Err. & $t$ & $P>|t|$ & {$[95 \%$ Conf. Interval] } \\
\hdashline import $\mid$ & .273575 & .0600218 & 4.56 & 0.000 & .1529567 & .3941932 \\
_cons $\mid$ & 1552228 & 799718.2 & 1.94 & 0.058 & -54866.12 & 3159322
\end{tabular}

Table 1 shows that there is a significant and positive relationship between import and export in Nigeria. Thus, the coefficient of import of about 0.273575 tells us that if export goes up by a unit, on average, import also goes up by about 0.273575 units that is, if export is increased by $100 \%$ on average, import will also be increased by about 27.36 in Nigeria. The result also shows that the R-square value of 0.2977 implies that about 29.77 percent of the total variations observed in the dependent variable were actually accounted for by the independent variable included in the model. However, the result of ANOVA table shows that the $F_{\text {cal }}$ value of 20.77 is highly significant as the prob $>\mathrm{F}=0.0000$ indicating that there is a significant different between import and export seaborne trade through Nigeria seaports.

Table 2a : Dickey - Fuller Test.

Null Hypothesis: EXPORTS has a unit root

Exogenous: Constant

Lag Length: 2 (Automatic based on SIC, MAXLAG=10)

\begin{tabular}{lcc}
\hline \hline & & t-Statistic \\
\hline \hline Elliott-Rothenberg-Stock DF-GLS test statistic & -0.673300 \\
\hline Test critical values: & 1\% level & -2.614029 \\
& $5 \%$ level & -1.947816 \\
& $10 \%$ level & -1.612492 \\
\hline \hline
\end{tabular}

*MacKinnon (1996) 
Table 2a above shows the result of Dickey Fuller test for unit root. The result revealed that the test statistic of (0.673300 ) is less than the critical values of tau at $1 \%, 5 \%$ and $10 \%$. Thus we do not reject the null hypothesis and conclude that the export data is non stationary over the years.

\section{Table 2b : Dickey - Fuller Test.}

Null Hypothesis: IMPORTS has a unit root

Exogenous: Constant

Lag Length: 0 (Automatic based on SIC, MAXLAG=10)

\begin{tabular}{llc}
\hline \hline & & t-Statistic \\
\hline \hline Elliott-Rothenberg-Stock DF-GLS test statistic & -0.142973 \\
\hline Test critical values: & $1 \%$ level & -2.612033 \\
& $5 \%$ level & -1.947520 \\
& $10 \%$ level & -1.612650 \\
\hline \hline
\end{tabular}

*MacKinnon (1996)

Table $2 \mathrm{~b}$ above shows the result of Dickey - Fuller unit root. The result revealed that the calculated test statistic of (- 0.142973$)$ is less than the critical values at $1 \% 5 \%$ and $10 \%$ level of significance. Thus we do not reject the null hypothesis of unit root. This also implies that the import data is non stationary over the years.

\section{Conclusion}

In practice most economic time series are non stationary. At the formal level, stationary can be checked by finding out if time series contains a unit root. In this research work the Dickey - fuller (DF) was used for this purpose. The result of the test shows that export and import data in Nigeria are non stationary over the years as the values of the test statistic are less than test critical values at $1 \%, 5 \%$ and $10 \%$ levels of significance. However, the OLS analysis to the differenced data which is stationary revealed that there is a significant relationship between import and export seaborne trade in Nigeria seaports between 1955 to 2005.

\section{Reference}

[1]. Achike, A. I, Onoja, A. O. and Herbert, B. C. (2011). Analysis of Determinants of Agricultural Foreign Direct Investment in Nigeria: The Nigerian Agricultural Journal vol.42 pp 1- 11

[2]. Bannerjee, Anindya, Junan Dolado, John W. Galbraith and David F. Hendry (1993) Integration, Error Correction and the Econometric Analysis of Non- Stationary Data Oxford: Oxford University Press.

[3]. Box, G.E.P. and G.M. Jenkins (1979) Time series Analysis Forecasting and Control. San Francisco: Holden Day.

[4]. Central Bank of Nigeria (2006). "Annual Report on Nigeria Port Plc" pp 47- 50.

[5]. Danilowska, Alina (2008). Preferential Macroeconmic Determinants of Agricultural Preferential Investmen Credit in Poland. A Paper Presented at 2008 International Congress. August 26-29 Ghent Belgium. Retrieved 25 $5^{\text {th }}$ November, 2011 from http://purl. umn.edu/4406.

[6]. Dickey, David A., and Wayne A. Fuller. 1979. Distribution of the Estimators for Autoregressive Time Series with a Unit Root. Journal of the American Statistical Association 74: 427-431.

[7]. Engle, R.F. and C.W.J Granger, (1987). Cointegration and Error Correction: Representation,Estimation and Testing. Econometrica vol. 55: pp 251-276

[8]. Granger, C. W. J. and Newbold, P. (1974)Spurious Regression in Econometrics. Journal of Econometrics, vol.2 (2) pp 111 - 120

[9]. Greene,W. H. (2008) Econometric Analysis Fifth edition Prentice Hall: New Jersey.

[10]. Gujarati, D. N. (2006), Essentials of Econometrics, $3^{\text {rd }}$ ed. McGraw-Hill, New York.

[11]. Gujarati, D. N. and Porter, D. C. (2009), Basic Econometrics, $5^{\text {th }}$ ed. McGraw-Hill, New York.

[12]. Nelson, Charles R. and Charles I. Plosser. 1982. Trends and Random Walks in Macroeconomic Time Series: Some Evidence and Implications. Journal of Monetary Economics 10:139-162.

[13]. Omekara C.O (1995) An introduction to Time Series,Okigwe:Alvan Publication.

[14]. Razaak, W.A. (2007). A Perspective on Unit Root and Cointegration in Applied Macroeconomics. International Journal of Applied Econometrics and Quantitative Studies vol. 4 (1)

[15]. Sims, Christopher A., James H. Stock, and Mark W. Watson. 1990. Influence in Linear Time

[16]. Series Models with Some Unit Roots. Econometrica 58: 113-144.

[17]. Stock, James H., and Mark W. Watson. 1988. Testing for Common Trends. Journal of the American Statistical Association 83: 1097-1107.

[18]. Stock, James H. 1994. Unit Roots, Structural Breaks, and Trends. In Handbook of Econometrics, vol. 4, eds. Robert F. Engle and Daniel L. McFadden, 2739-2841. Amsterdam: North- Holland. 